\title{
Chemical Constituents and Antimicrobial Activity of Soil Fungus Aspergillus sp. FRIZ12
}

\author{
Pinheiro, E. A. A.; Pina, J. R. S.; Paixão, L. K. O.; Siqueira, J. E. S.; Feitosa, \\ A. O.; Carvalho, J. M.; Marinho, P. S. B.; Marinho, A. M. R.*
}

Rev. Virtual Quim., 2018, 10 (5), 1438-1445. Data de publicação na Web: 10 de setembro de 2018

http://rvq.sbq.org.br

\section{Constituintes Químicos e Atividade Antimicrobiana do Fungo de Solo Aspergillus sp. FRIZ12}

Resumo: O presente trabalho relata o isolamento de nove compostos da biomassa do fungo de solo Aspergillus sp. FRIZ12. Os compostos 2-benzil-4H-piran-4-ona (1), flavasperona (2), 5- (hidroximetil) furfural (3), uridina (4), ergosterol (5), peróxido de ergosterol (6), cerivisterol (7), estigmasterol (8) e sitosterol (9) foram isolados por métodos cromatográficos, e as estruturas foram identificadas por RMN, EM e comparação com dados da literatura. O composto 1 está sendo relatado pela primeira vez no gênero Aspergillus e pela segunda vez como um produto natural. Os compostos 1 e 2 mostraram moderada atividade antimicrobiana

Palavras-chave: Aspergillus; metabólitos secundários; fungos de solo; atividade antimicrobiana.

\section{Abstract}

The present work reports the isolation of nine biomass compounds of soil fungus Aspergillus sp. FRIZ12. The compounds 2-benzyl-4H-pyran-4-one (1), flavasperone (2), 5-(hydroxymethyl) furfural (3), uridin (4), ergosterol (5), ergosterol peroxide (6), cerivisterol (7), stigmasterol (8) and sitosterol (9) were isolated by chromatographic methods, and the structures were identified by NMR, MS, and comparison with literature data. Compound $\mathbf{1}$ is being reported for the first time in the genus Aspergillus and for the second time as a natural product. Compounds $\mathbf{1}$ and $\mathbf{2}$ showed moderate antimicrobial activity.

Keywords: Aspergillus; secondary metabolites; soil fungi; antimicrobial activity.

\footnotetext{
*Universidade Federal do Pará, Faculdade de Química, Rua Augusto Corrêa nº1, CEP 66075110, Belém-PA, Brasil.

Mandrey@ufpa.br

DOI: $\underline{10.21577 / 1984-6835.20180097}$
} 


\title{
Chemical Constituents and Antimicrobial Activity of Soil Fungus Aspergillus sp. FRIZ12
}

\author{
Eduardo A. A. Pinheiro, Jeferson R. S. Pina, Luanna K. O. Paixão, José E. S. \\ Siqueira, André O. Feitosa, Josiwander M. Carvalho, Patrícia S. B. \\ Marinho, Andrey M. R. Marinho*
}

Universidade Federal do Pará, Faculdade de Química, Rua Augusto Corrêa n 01, CEP 66075110, Belém-PA, Brasil.

*andrey@ufpa.br

Recebido em 17 de maio de 2018. Aceito para publicação em 31 de agosto de 2018

1. Introduction

2. Experimental

2.1. General Procedures

2.2. Microorganism isolation

2.3. Culture of Aspergillus sp. FRIZ12 in rice and isolation of the chemical constituents

2.4. Antimicrobial assay

\section{Results and Discussion}

\subsection{Isolated compounds}

3.2. Antimicrobial bioassay

\section{Conclusion}

\section{Introduction}

The soil is an ecological niche highly explored by microorganisms producing biologically active natural products, including antibiotics. Most antibiotics are isolated from Streptomycetes and fungi, commonly found living in the soil. Current researches have emphasized the need to explore new niches, such as tropical forests, marine sponges, mangroves, and endophytes to discovery pharmacologically active compounds. ${ }^{1,2}$
Fungi of the genus Aspergillus (Phylum Ascomycota, Family Trichocomaceae) can be isolated from soil, water, vegetation, decomposition material, and air. In general, Aspergillus fungi are frequent in regions with tropical and subtropical climate, and many species produce compounds with antimicrobial activity. ${ }^{3}$

The World Health Organization has considered the bacterial resistance to antibiotics a serious threat to public health. The bacteria Escherichia coli (Phylum Proteobacteria, Family Enterobacteriaceae), Pseudomonas aeruginosa (Phylum 
Proteobacteria, Family Pseudomonadaceae), Bacillus subtilis (Phylum Firmicutes, Family Bacillaceae), Staphylococcus aureus (Phylum Firmicutes, Family Staphylococcaceae) and Salmonella typhimurium (Phylum Proteobacteria, Family Enterobacteriaceae), are frequently associated with disease in humans and animals. The increasing phenomenon of bacterial resistance to antibiotics has led to the need to discover new antimicrobial agents and methods. ${ }^{4}$ Obtaining fungal compounds has been an important strategy for the discovery of new bioactive compounds, since it is known that the fungi are great producers of secondary metabolites, many of them being biologically active. ${ }^{5-9}$

Thus, the present work aimed at obtaining compounds with antimicrobial activity from the fungus Aspergillus sp. FRIZ12, in addition to studying their chemistry. Nine compounds were isolated from the biomass extracts: 2benzyl-4H-pyran-4-one (1), flavasperone (2), 5-(hydroxymethyl) furfural (3), uridin (4), ergosterol (5), ergosterol peroxide (6), cerivisterol (7), sitosterol (8), and stigmasterol (9) (Figure 1). Compound $\mathbf{1}$ is reported for the first time in the genus Aspergillus and for the second time as a natural product.
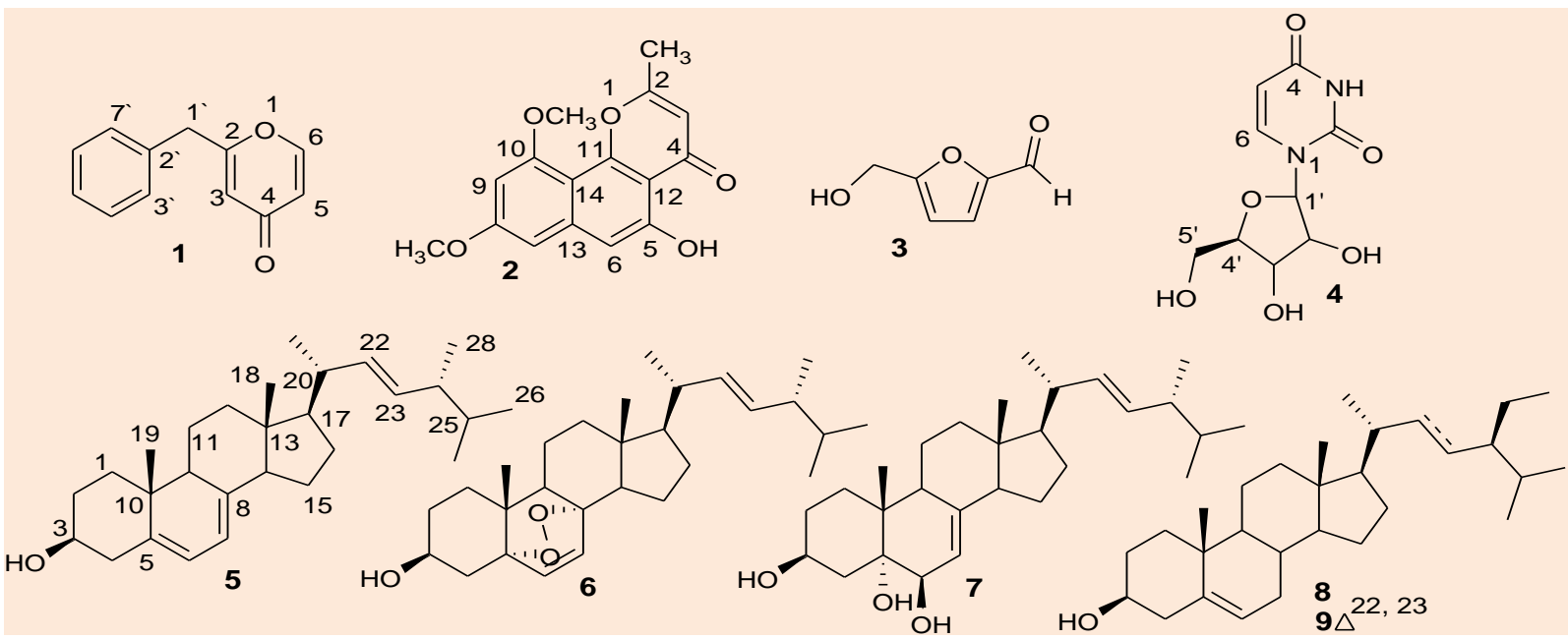

Figure 1. Compounds isolated from Aspergillus sp. FRIZ12

\section{Experimental}

\subsection{General Procedures}

The ${ }^{1} \mathrm{H}$ and ${ }^{13} \mathrm{C}$ NMR experiments were recorded in an NMR spectrometer (Mercury 300, Varian, Oxford, Oxford shire, UK) with $\mathrm{CDCl}_{3}\left(\right.$ Cambridge $\left.^{\circledR}\right)$ as solvent and standard. MS spectra were carried out in the a mass spectrometer (Acquity TQD, Waters, Milford, $M A, U S A)$ using electrospray ionization in positive ion mode ESI(+). Chemical shifts were given in delta $(\delta)$ and constants coupling $(J)$ are given in Hertz $(\mathrm{Hz})$.

\subsection{Microorganism isolation}

For the isolation of the fungus Aspergillus sp. FRIZ12, the serial suspension technique was used. $1 \mathrm{~g}$ of soil, previously sieved in a 2 $\mathrm{mm}$ mesh, was transferred to a test tube containing $9 \mathrm{~mL}$ of sterilized distilled water and agitated in a Vortex (100 rpm) for 10 minutes. From this solution was carried out serial dilutions until 1:1000 dilution. Then, 0.1 $\mathrm{mL}$ was added in Petri dishes containing BDA culture medium and incubated for seven days. ${ }^{10}$ After the growth of the colonies the fungi were isolated by successive samplings. The fungus FRIZ12 was identified by 
morphological analysis on an optical microscope as being of the genus Aspergillus.

\subsection{Culture of Aspergillus sp. FRIZ12 in rice and isolation of the chemical constituents}

Fifteen Erlenmeyer flasks (1000 mL), containing $200 \mathrm{~g}$ of rice ("Uncle Ben's ${ }^{\circledR ”}$ ) and $75 \mathrm{~mL}$ of water each, were autoclaved for 45 min at $121{ }^{\circ} \mathrm{C}$. Small pieces of PDA containing mycelium of Aspergillus sp. FRIZ12 were added to 13 Erlenmeyer flasks under sterile conditions, and then the Erlenmeyer flasks were incubated at $25^{\circ} \mathrm{C}$ for 25 days for colony growth, two Erlenmeyer flaks were used as control. Biomass was macerated with hexane, ethyl acetate, and methanol, in which the hexane (13.2 g), ethyl acetate $(8.3 \mathrm{~g})$, and $\mathrm{MeOH}(150.7 \mathrm{~g})$ extracts were obtained after evaporation of the resulting solutions in a rotary evaporator. The ethyl acetate extract was fractioned on silica gel column chromatography using as mobile phase hexane, hexane/ethyl acetate (7:3, 1:1, 3:7), ethyl acetate, ethyl acetate/methanol (1:1) and methanol resulting in 7 fractions. The fraction ethyl acetate after chromatographed on silica gel CC by using hexane, ethyl acetate, and methanol as mobile phase in a gradient of polarity, monitored by TLC the following chemical constituents were isolated 2-benzyl$4 \mathrm{H}$-pyran-4-one $(\mathbf{1}, 5.2 \mathrm{mg})$, flavasperone (2, $5.3 \mathrm{mg}), 5$-(hydroxymethyl) furfural $(3,58.6$ $\mathrm{mg})$, uridin $(4,2.4 \mathrm{mg})$. The fraction hexane/ethyl acetate 7:3 after chromatographed on silica gel CC by using hexane, ethyl acetate, and methanol as mobile phase in a gradient of polarity, monitored by TLC the compound ergosterol $(5,50.8 \mathrm{mg})$, ergosterol peroxide $(6,69.5 \mathrm{mg})$, cerivisterol (7, $43.3 \mathrm{mg})$, sitosterol + stigmasterol $(8+9,58.9 \mathrm{mg})$ were isolated.

\subsection{Antimicrobial assay}

The Susceptibilities of bacteria to compounds $\mathbf{1}$ and $\mathbf{2}$ were determined by microbroth dilution assay as recommend by the Clinical and Laboratory Standards Institute (CLSI). ${ }^{11}$ The assay was carried out on 96 well plates with $100 \mu \mathrm{L}$ of Mueller Hinton Broth (MHB), $100 \mu \mathrm{L}$ of test compounds, and $5 \mu \mathrm{L}$ of test bacteria at $1.0 \times 10^{8} \mathrm{CFU} \cdot \mathrm{mL}^{-1}$, followed by incubation at $37^{\circ} \mathrm{C}(24 \mathrm{~h})$. Compounds 1 and 2 were dissolved in dimethyl sulfoxide at the initial concentration of $500 \mu \mathrm{g} \cdot \mathrm{mL}^{-1}$. The microorganisms used in the antimicrobial assay were Escherichia coli (ATCC 25922), Pseudomonas aeruginosa (ATCC 27853), Bacillus subtilis (ATCC 6633), Staphylococcus aureus (ATCC 25923), and Salmonella typhimurium (ATCC 14028), obtained from the Instituto Evandro Chagas, Belém - Brazil. Bioactivity was observed by absence of red coloration in the wells after addition of $10 \mu \mathrm{L}$ of 2,3,5-triphenyltetrazolium chloride. Penicillin, vancomycin, and tetracycline (25 $\mu \mathrm{g} \cdot \mathrm{mL}^{-1}$ ) were used as positive control. The culture medium (MHB only) was used as negative control.

\section{Results and Discussion}

\subsection{Isolated compounds}

In the present work, nine compounds were isolated from the ethyl acetate extract of the Aspergillus sp. FRIZ12 biomass, namely: 2benzyl-4H-pyran-4-one (1), flavasperone (2), 5-(hydroxymethyl) furfural (3), uridin (4), ergosterol (5), ergosterol peroxide (6), cerivisterol (7), sitosterol (8), and stigmasterol (9). Compound $\mathbf{1}$ is reported for the first time in the genus Aspergillus and for the second time as a natural product.

Compound $\mathbf{1}$ was isolated as a yellow crystalline solid, soluble in dichloromethane. The mass spectrum was observed at $m / z 187$ $[\mathrm{M}+\mathrm{H}]^{+}$which together with the NMR data, made possible to propose the molecular formula $\mathrm{C}_{12} \mathrm{H}_{10} \mathrm{O}_{2}$. In the ${ }^{1} \mathrm{H}$ NMR spectrum, a multiplete signal was observed at $\delta_{H} 7.24-\delta_{H}$ 7.33 , attributed to the hydrogens of the 
monosubstituted aromatic ring. The aromatic ring was confirmed by HETCOR correlation of the $\delta_{H} 7.24-\delta_{H} 7.33$ signals with signals of the aromatic carbons $\delta_{c} 127.6,128.9,129.1$, and 134.4. The signal in the ${ }^{1} \mathrm{H}$ NMR spectrum at $\delta_{\mathrm{H}} 3.83\left(\mathrm{~s}, 2 \mathrm{H}, \mathrm{H}-1^{\prime}\right)$ was attributed to benzylic hydrogen. Hydrogen $\mathrm{H}-1^{\prime}$ showed $\mathrm{HMBC}$ correlation with aromatic carbons C-3' and C$7^{\prime}$, and olefinic carbon C-2; moreover, the benzylic hydrogen $\mathrm{H}-1^{\prime}$ showed COSY correlation with $\mathrm{H}-3\left(\delta_{\mathrm{H}} 6.21, d l, 1 \mathrm{H}, \mathrm{J}=2.4 \mathrm{~Hz}\right)$. Through the $\mathrm{HMBC}$ and COSY correlation to $\mathrm{H}$ 3 (Figure 2), it was possible to propose a pyran ring to compound 1 . Through the $\mathrm{HMBC}$ correlation observed to $\mathrm{H}-6$ with the signal at $\delta_{c} 179.3$, it was possible to attribute the position of $\alpha, \beta$-unsaturated carbonyl group on $\mathrm{C}-4$. Through the $\mathrm{HMBC}$ correlation to $\mathrm{H}-3$ with benzylic carbon $\mathrm{C}^{-} \mathbf{1}^{\prime}\left(\delta_{c} 40.0\right)$, it was possible to determinate the exact place of the link between benzylic and pyran rings. Compound 1 was identified as the gammapyran 2-benzyl-4H-pyran-4-one. This compound was previously isolated from an endophytic fungus from mangrove plants ${ }^{12}$ and is being reported for the first time in the genus Aspergillus and for the second time as a natural product. Table 1 shows the ${ }^{1} \mathrm{H}$ and ${ }^{13} \mathrm{C}$ NMR data to compound 1.

Compound $\mathbf{2}$ was isolated as a yellow crystalline solid, soluble in dichloromethane. The mass spectrum peak at $\mathrm{m} / \mathrm{z} 287[\mathrm{M}+\mathrm{H}]^{+}$ allowed to calculate the molecular formula $\mathrm{C}_{16} \mathrm{H}_{14} \mathrm{O}_{5}$. Through analysis of the NMR data, compound $\mathbf{2}$ was identified as the gammapyran flavasperone. ${ }^{13}$ The compound flavasperone had been isolated from Aspergillus species and recent works had showed the cytotoxic activities and inhibition of the ACAT2 isoenzyme by compound. ${ }^{13}$

Table 1. ${ }^{1} \mathrm{H}$ and ${ }^{13} \mathrm{C}$ NMR data to compound $1\left(\mathrm{CDCl}_{3}, 300 \mathrm{MHz}\right)$.

\begin{tabular}{ccc}
\hline $\mathbf{n}$ & ${ }^{1} \mathbf{H}(\boldsymbol{\delta}$, mult., $\mathbf{J}$ in $\mathrm{Hz})$ & ${ }^{13} \mathbf{C}$ \\
\hline 2 & - & 168.5 \\
3 & $6.21(d l, 1 \mathrm{H} ; J=2.4 \mathrm{~Hz} ; \mathrm{H}-3)$ & 115.5 \\
4 & - & 179.3 \\
5 & $6.34(d d, 1 \mathrm{H} ; J=5.7$ and $2.4 \mathrm{~Hz} ; \mathrm{H}-5)$ & 116.6 \\
6 & $7.70(d, 1 \mathrm{H} ; J=5.7 \mathrm{~Hz} ; \mathrm{H}-6)$ & 155.4 \\
$1^{\prime}$ & $3.83\left(s, 2 \mathrm{H}, \mathrm{H}-1^{\prime}\right)$ & 40.0 \\
$2^{\prime}$ & - & 134.4 \\
$3^{\prime}$ & $7.24(\mathrm{~m})$ & 128.9 \\
$4^{\prime}$ & $7.33(\mathrm{~m})$ & 129.1 \\
$5^{\prime}$ & $7.33(\mathrm{~m})$ & 127.6 \\
$6^{\prime}$ & $7.33(\mathrm{~m})$ & 129.1 \\
$7^{\prime}$ & $7.24(\mathrm{~m})$ & 128.9 \\
\hline
\end{tabular}

Compound 3 was identified as 5(hydroxymethyl) furfural, it is one of the major components of honey quality measurement, and studies have shown that this compound has cytotoxic, genotoxic, mutagenic, and carcinogenic activities. ${ }^{14}$ In turn, compound $\mathbf{4}$ has been identified as nucleoside uridine, ${ }^{15}$ previous works have shown that uridine has antiviral activity. ${ }^{16}$

The sterols ergosterol (5), ergosterol peroxide (6), cerivisterol (7), sitosterol (8), and stigmasterol (9) were isolated by chromatographic procedures and identified by NMR and with literature data. ${ }^{17-19}$ 
Analysis of the control extracts by MS showed the absence of the isolated compounds in the culture medium, confirming that the isolated compounds are secondary metabolites produced by the fungus Aspergillus FRIZ12 and not from the culture medium.

\subsection{Antimicrobial bioassay}

Bacterial resistances to antibiotics have increased to dangerously high levels in all parts of the World. ${ }^{20}$ In this context, it is necessary to search for new antimicrobial agents, which agrees with the chemistry of fungi that are great producers of bioactive secondary metabolites. Several studies have led to the isolation of compounds with antimicrobial activities. Thus, in the present work, antimicrobial bioassays were performed with isolated compounds. The compounds 2benzyl-4H-pyran-4-one (1) and flavasperone (2) showed bacteriostatic activities up to the lowest concentration tested $\left(7.81 \mu \mathrm{g} \cdot \mathrm{mL}^{-1}\right)$ against the bacteria $B$. subtilis, E. coli, and $P$. aeruginosa. As for $S$. aureus, both compounds $\mathbf{1}$ and $\mathbf{2}$ showed bacteriostatic activities up to the concentrations of $31.25 \mu \mathrm{g} \cdot \mathrm{mL}^{-1}$ and 15.62 $\mu \mathrm{g} \cdot \mathrm{mL}^{-1}$, respectively. Against the bacterium $S$. typhimurium, compounds $\mathbf{1}$ and $\mathbf{2}$ were active up to the concentrations of $62.5 \mu \mathrm{g} \cdot \mathrm{mL}^{-1}$ and $15.6 \mu \mathrm{g} \cdot \mathrm{mL}^{-1}$.

Barrow and MuCulloch ${ }^{21}$ carried out a review on the biological importance of gamma-pyrans, which showed that they have a wide occurrence, in addition to a large range of biological activities, such as antimicrobial, antiviral, insecticide, and antiestrogen. Choque et al., ${ }^{22}$ also carried out a review and suggest that gamma-pyrans are of large industrial interest due to their biological activities, which can be useful to pharmaceutical, cosmetics, and food industries.

The data obtained in this work agree with the literature for the activities of gammapyrans. However, none of these studies reported the antimicrobial activity of the compound flavasperone, this being the first report on the antimicrobial activity of this gamma-pyran against the bacteria $B$. subtilis, $E$. coli, $P$. aeruginosa, $S$. aureus, and $S$. typhimurium.

\section{Conclusion}

The chemical study of soil fungus Aspergillus sp. FRIZ12 led to the isolation of the nine compounds, with 2-benzyl-4H-pyran4-one (1) being reported for the first time in the genus Aspergillus and for the second time as a natural product. The compounds flavasperone (2) and 2-benzyl-4H-pyran-4-one (1) were tested against the bacteria $B$. subtilis, $E$. coli, $P$. aeruginosa, $S$. aureus, and $S$. typhmirium, showing good activity. Thus, it can be evidenced that Aspergillus sp. FRIZ12 has potential to produce antimicrobial compounds, especially regarding the production of gamma-pyrans.

\section{Acknowlwedgments}

The authors thanks to the CNPq, CAPES, FAPESPA and VALE S.A. for financial support.

\section{References}

${ }^{1}$ Garcia, W. M.; Zago, B. W.; Nunes, J. R. S.; Carvalho, I. F. Diversity of filamentous fungi in Cerrado soil under native vegetation. Revista Brasileria de Biociências 2015, 13, 245. [Link]

${ }^{2}$ Kumar, C. G.; Mongolla, P.; Joseph, J.; Nageswar, Y. V. D.; Kamal, A. Antimicrobial activity from the extracts of fungal isolates of soil and dung samples from Kaziranga National Park, Assam, India. Journal de Mycologie Médicale 2010, 20, 283. [Link]

${ }^{3}$ Ibrahim, S. R. M.; Elkhayat, E. S.; Mohamed, G. A.; Khedr, A. I. M.; Fouad, M. A.; Kotb, M. H. 
R.; Ross, S. A. Aspernolides F and G, new butyrolactones from the endophytic fungus Aspergillus terreus. Phytochemistry Letters 2015, 14, 84. [Crossref]

${ }^{4}$ Takahashi, J. A.; Castro, M. C. M.; Souza, G. G.; Lucas, E. M. F.; Bracarense, A. A. P.; Abreu, L. M.; Marriel, I. E.; Oliveira, M. S.; Floreano, M. B.; Oliveira, T. S. Isolation and screening of fungal species isolated from Brazilian cerrado soil for antibacterial activity against Escherichia coli, Staphylococcus aureus, Salmonella typhimurium, Streptococcus pyogenes and Listeria monocytogenes. Journal Mycology Médicale 2008, 18, 198. [Crossref]

${ }^{5}$ Chen, G. Y.; Ruan, B. H.; Yang, Y. B.; Wang, Q.; Li, X. Z.; Luo, N.; Yang, X. Q.; Zhao, L. X. Secondary metabolites of the fungus Aspergillus terreus Chemistry of Natural Compounds 2018, 54, 415. [Crossref]

${ }^{6}$ Strobel, G.; Daisy, B. Bioprospecting for microbial endophytes and their natural products. Microbiology and Molecular Biology Review 2003, 67, 491. [PubMed] [Crossref]

${ }^{7}$ Zhai, M. M.; Qi, F. M.; Li, J.; Jiang, C. X.; Hou, Y.; Shi, Y. P.; Di, D. L.; Zhang, J. W.; Wu, Q. X. Isolation of secondary metabolites from the soil derived fungus Clonostachys rosea YRS06, a biological control agent, and evaluation of antibacterial activity. Journal of Agricultural and Food Chemistry 2016, 64, 2298. [Crossref]

${ }^{8}$ Silva, G. B. P. G.; Silvino, K. F.; Bezerra, J. D. P.; Farias, T. G. S.; Araújo, J. M.; Tânia Stamford, T. L. M. Antimicrobial activity of Phoma sp. URM 7221: An endophyte from Schinus terebinthifolius Raddi (Anacardiaceae). African Journal of Microbiology Research 2017, 11, 1. [Crossref]

${ }^{9}$ Liang, T.; Fang, Y.; Zheng, J.; Shao, C. Secondary metabolites isolated from the Gorgonian-derived fungus Aspergillus ruber and their antiviral activity. Chemistry of Natural Compounds 2018, 54, 559. [Crossref]

${ }^{10}$ Cordeiro, J. S.; Tese de Doutorado, Universidade Federal do Pará, 2016. [Link]

${ }^{11}$ CLSI. Methods for Dilution Antimicrobial Susceptibility Tests for Bacteria That Grow Aerobically; Approved Standard Ninth Edition.
CLSI document M07-A9. Wayne, PA: Clinical and Laboratory Standards Institute; 2012.

12 Huang, Z.; Shao, C.; Chen, Y.; She, Z.; Lin, Y. Pyrones in metabolites of marine mangrove endophytic fungus (No ZZF79) from the South China Sea. Zhongshan Daxue Xuebao, Ziran Kexueban 2007, 46, 113. [Crossref]

${ }^{13}$ Sakai, K.; Ohte, S.; Ohshiro, T.; Matsuda, D.; Masuma, R.; Rudel, L. L.; Tomada, H. Selective Inhibition of Acyl-CoA:cholesterol Acyltransferase 2 Isozyme by Flavasperone and Sterigmatocystin from Aspergillus Species. The Journal of Antibiotics 2008, 61, 568. [Crossref]

${ }^{14}$ Silva, S. J. N.; Schuch, P. Z.; Vainstein, M. H.; Jablonski, A. Determination of 5hydroxymethyl-2-furaldehyde in honey by micellar eletrokinetic capillary electrophoresis. Ciência e Tecnologia de Alimententos 2008, 28 (supl), 46. [Crossref]

${ }^{15}$ Souza, E. M. C.; Silva, E. L.; Marinho, A. M. R.; Marinho, P. S. B. (4S)-4,8-dihydroxy-1tetralone and other chemical constituents from Pestalotiopsis sp. EJCO7, endophytic from Bauhinia guianensis. Anais da Academia Brasileira de Ciências 2016, 88, 29. [Crossref]

${ }^{16}$ Pinto, A. C.; Silva, D. H. S.; Bolzani, V. S.; Lopes, N. P.; Epifanio, R. A. Produtos naturais: atualidade, desafios e perspectivas. Química Nova 2002, 25, 45. [Crossref]

${ }^{17}$ Carvalho, J. M.; Paixão, L. K. O.; Dolabela, M. F.; Marinho, P. S. B.; Marinho, A. M. R. Fotoesteróis isolados do fungo endofítico Colletotrichum gloeosporioides (Melanconiaceae). Acta Amazonica 2016, 46, 69. [Crossref]

${ }^{18}$ Fan, N. W.; Chang, H. S.; Cheng, M. J.; Chan, H. Y.; Hsieh, S. Y.; Liu, T. W.; Chen, S. W.; Yuan, G. F.; Chen, I. S. New metabolites from the endophytic fungus Mollisia sp. Chemistry of Natural Compounds 2016, 52, 585. [Crossref]

${ }^{19}$ Tang, H. Y.; Zhang, Q.; Li, H.; Gao, J. M. Antimicrobial and allelopathic metabolites produced by Penicillium brasilianum. Natural Product Research 2015, 29, 345. [Crossref]

${ }^{20}$ Vimal, V.; Rajan, B. M.; Kannabian, K. Antimicrobial of marine actinomycete 
Nocardiopsis sp. VITSVK 5 (FJ973467). Asian Journal of Medical Sciences 2009, 1, 57. [Link]

${ }^{21}$ Barrow, R. A.; MuCulloch, M. W. B. Linear naphtho-gamma-pyrones: a naturally occurring scaffold of biological importance. Mini-Reviews in Medicinal Chemistry 2009, 9, 273. [PubMed] [Crossref]
${ }^{22}$ Choque, E.; Rayess, Y. E.; Raynal, J.; Mathieu, F. Fungal naphtho- $\gamma$-pyrones secondary metabolites of industrial interest. Applied Microbiology and Biotechnology 2015, 99, 1081. [Link] 